\title{
Influences of Community Participation on School Infrastructure Policy Implementation and Performance of Construction Projects
}

\author{
Stephen J. Kamau' ${ }^{1}$, Charles M. Rambo², John M. Mbugua ${ }^{2}$ \\ ${ }^{1}$ School of Business and Economics, Kirinyaga University, Kirinyaga, Kenya \\ ${ }^{2}$ School of Open and Distance Learning, University of Nairobi, Nairobi, Kenya \\ Email: skamau@kyu.ac.ke
}

How to cite this paper: Kamau, S. J., Rambo, C. M., \& Mbugua, J. M. (2021). Influences of Community Participation on School Infrastructure Policy Implementation and Performance of Construction Projects. Open Journal of Social Sciences, 9, 173-187.

https://doi.org/10.4236/jss.2021.93012

Received: October 9, 2020

Accepted: March 14, 2021

Published: March 17, 2021

Copyright $\odot 2021$ by author(s) and Scientific Research Publishing Inc. This work is licensed under the Creative Commons Attribution International License (CC BY 4.0).

http://creativecommons.org/licenses/by/4.0/

\begin{abstract}
Community participation has been used in the developing world as a fallback when government efforts to establish schools and education within communities fail or are inadequate. The study was conducted in Somaliland-a state in the horn of Africa that is in the process or rebuilding schools and reestablishing education after the wanton destruction of the education infrastructure during the Somali civil war. With a school infrastructure regulatory policy having been established to set standards for school infrastructure, the study examined how community participation influenced the effect of school infrastructure policy implementation on the performance of construction projects in public primary schools. The study was set in Somaliland and targeted all public primary school headteachers in all the administrative regions and District Education Officers (DEO) in all the Districts. A cross-sectional survey guided by pragmatism, the study collected data from 20 DEOs and 247 headteachers. Headteachers filled questionnaires while DEOs were interviewed. Primary schools that reported low levels of community participation also realized a positive influence of school infrastructure policy implementation on the performance of construction projects, while schools that reported moderate and high levels of community participation did not. Community participation doesn't only bring positive influences to projects but negative influences as well. Community participation has a significant low and negative partial moderation effect on the relationship between school infrastructure policy implementation and performance of construction projects. A linear model exists among the three variables.
\end{abstract}

\section{Keywords}

Community Participation, School Infrastructure Policy, Performance, 
Construction Projects, Headteachers, Primary Schools, Somaliland, Community Education Committees, Education, Public Schools, Infrastructure Facilities, Infrastructure Projects, Moderation

\section{Introduction}

To provide education, countries develop education systems and build requisite infrastructure. Among the components that make up the education policy is the school infrastructure policy which sets standards for schools to adhere to when establishing school infrastructure thereby influencing the school infrastructure projects the schools mount. The aim is to ensure quality learning facilities, the safety of learners and a favourable learning experience for the learners among others. In developing countries, where government capitation to finance school constructions is inadequate or lacking, communities are forced to step in for their own sake.

Developing countries often find it difficult to cope with the growing demand for education and often lag in expanding their educational infrastructure resulting in a state of inadequacy (Sifuna \& Sawamura, 2009). This has especially been escalated by free and compulsory primary education for all, adopted internationally (UNESCO, 2014; Sifuna \& Sawamura, 2009). Faced with this challenge, governments often engage the private sector to invest in education and supplement the school placement vacancies available in public schools (Damon, Glewwe, Wisniewski, \& Sun, 2016). Another strategy has been involving local communities in the construction of schools in their areas and school infrastructural development activities.

Globally the effects of civil war on education are felt in terms of destruction of school infrastructure, diversion of state funds from education to war, the collapse of educational institutions, stoppage of learning and conscription of school pupils and students to the military or rebel forces (Lai \& Thyne, 2007). These effects are felt many years after the end of the war. To restore education, reconstruction of schools is gradually undertaken. Construction projects are mounted across the schools to restore school infrastructure and establish new school facilities.

Somaliland's school infrastructure was vastly ravaged and destroyed during the Somalia civil war in the 1980s and early 1990s. Somaliland restored its independence in 1991 and began to restore peace. Education requires a peaceful environment to function. With financing from international donors, and NGOs Somaliland began restoring education. This entailed restoring school infrastructure, training and employing teachers. The government, short of funds to finance education among other competing interest turned to community participation. Communities were mobilized to restore schools and education in their areas. Community education committees (CECs) were formed to oversee school restoration and development. Over time, many school construction projects have been 
mounted throughout the state. The government has also gradually introduced a school infrastructure policy in various policy documents among them The Education Sector Strategic Development Plans [ESSDP] policies of 2007-2011, 20122016, and 2017-2021.

The study was set in the State of Somaliland which has been in the process of restoring education and reconstructing schools that were ravaged by the civil war.

\section{Concepts of the Study}

Traditionally communities are perceived as consisting of persons in social interactions bound by having shared ties that they are cognizant of and which tend to change over time (Burns \& Taylor, 2000). Governments participate communities in education development as a way of tapping social capital, supplementing government capitation and also empowering the community.

Successful community participation results in empowered communities that can engage in various facets of education support including readily donating resources (physical, human and economic) for the benefit of education and schools (De Wit, 2010; Gertler, Patrinos, \& Rubio-Codina, 2008). One approach to deliver this outcome is Community Based Development (CBD), which refers to projects that participate beneficiaries actively in the entire project cycle (Cooke \& Kothari, 2010) founded on the tenets of inclusion, empowerment, sustainability, good governance, poverty reduction, effectiveness and efficiency (Chambers, 2013). The results of community participation in school projects include improved equitable access, better quality facilities, higher retention, and improved general school performance (Burki, Perry \& Dillinger, 2009; Bengle \& Sorensen, 2016). In this study, community participation is regarded in the context of local communities participating in school construction projects in local public primary schools within their community.

School infrastructure policy regulates and sets standards for physical infrastructure development in educational institutions (UNESCO, 2014). The infrastructure policy aims to ensure that pupils and students are taught in quality educational facilities that guarantee universal and equitable access to education in a fit-for-purpose, learning environment that is safe, hygienic and which complies with all the agreed minimum standards. School infrastructure policy implementation refers to the aspects of interpreting and applying the policy by regulatees on one hand and administration/governance or enforcement of the policy by the regulator on the other (Coglianese, 2012). It is operationalized into policy interpretation and policy governance (Brown, Stern, Tenenbaum, \& Gencer, 2006).

School infrastructure policy is regulatory and sets boundaries and standards that school infrastructures should meet. Inspections and certifications are often done to ensure compliance. Once such a policy is established, schools and other educational institutions have no option but to implement the policy and comply 
with its provisions. This affects the infrastructure projects the school undertakes and the way they mount them.

School infrastructure projects often take the form of construction projects. These are establishment works of physical components of a built environment in a school among them buildings and structures. The performance of a construction project can be measured by the level of realization of a specified or preplanned matrix of results that the project set out to realize (Chan \& Chan, 2004). The criteria for assessing the success or failure of a project is commonly referred to as project performance indicators. Certain parameters are considered when determining whether a project is successful or not, among them: completion within the set timeline and budget, the realization of the scope and quality specifications, and customer satisfaction. Projects that miss all or some of their set parameters may be considered failed or partially successful. Concerning a project organization; parameters such as projects initiated, completed, finished on time, completed without exceeding the budget and, the value and size of the projects undertaken are indicators of the organizations' projects' performance (Jiang \& Carroll, 2009).

Different authors have proposed different performance indicators based on empirical studies: Vandevelde, Dierdonck, \& Debackere (2002) proposed seven indicators for project performance: respect for the project budget, specifications and time; contributing to the achievement of the organization, creating and transferring knowledge, commercial success and financial success. Chan, Scott, \& Lam (2002) advanced a framework of performance measures for construction projects in which they proposed that managers distinguish between objective measures and subjective measures and, measure the success of a project at the pre-construction, construction, and post-construction phases. This approach was further refined by Chan \& Chan (2004) who proposed a set of subjective and objective indicators for measuring construction projects' performance. Objective indicators: project delivery time, delivery speed, completion time variance, unit cost, cost variance, net present value, accident occurrence rates and, environmental impact assessment scores. Subjective indicators: client satisfaction, contractor satisfaction, design team satisfaction, functionality, quality realized and, the satisfaction of beneficiaries (Chan \& Chan, 2004). This study adopted a combination of the Chan and Chan (2004) objective and subjective indicators to measure the performance of construction projects.

\section{Objective of the Study}

School infrastructure policy set standards that schools' management have to observe as they mount infrastructure projects to meet the demand for education. The study sought to establish whether community participation in school infrastructure projects moderated the effect of school infrastructure policy implementation on the performance of construction projects.

The study sought to test the model in Figure 1. 


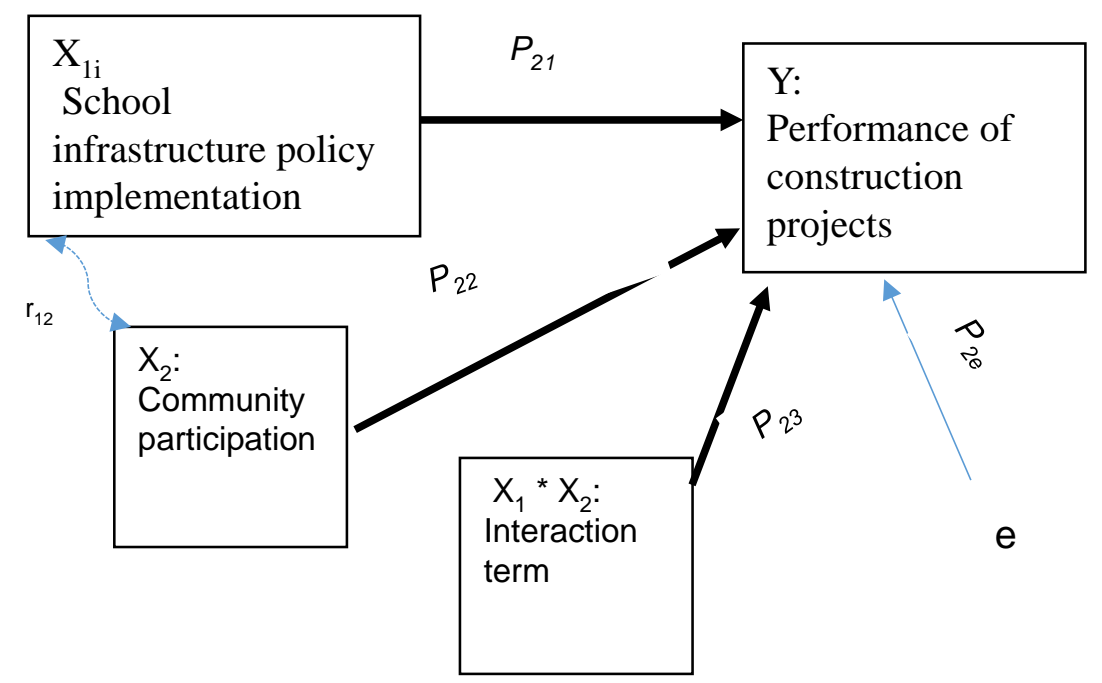

Figure 1. Moderation model.

The following null hypotheses were tested:

$\mathrm{H}_{\mathrm{O}}$ a: School infrastructure policy implementation $\left(X^{1}\right)$ has no total effect on the performance of construction projects $(Y)$.

$\mathrm{H}_{\mathrm{o}}$ b: Community participation $\left(X^{2}\right)$ does not moderate the relationship between school infrastructure policy implementation $\left(X^{1}\right)$ and the performance of construction projects $(Y)$.

\section{Research Methodology}

The study was guided by the pragmatism philosophy. Of the existing paradigms transformative and pragmatism are considered suitable for mixed methods research (Hall, 2013). Pragmatism is preferred by social scientists using mixed methods research since it lets the researcher adopt the most suitable methodology to investigate the problem rather than conform the methodology of study to a certain pre-existing paradigm (Kaushik and Walsh, 2019).

The study was a cross-sectional survey using a correlational design and mixed methods of inquiry. The target population were 920 headteachers in 920 public primary schools in Somaliland and 82 District Education Officers (DEOs) in the 13 administrative regions in the state (total 1002 at the time of the study). Headteachers and DEOs were the units of observation while the schools were the units of analysis. Headteachers completed questionnaires while DEOs were interviewed.

The study used the Cochran large population sample size formula $\left(n=Z^{2}\right.$ $\left.(P)(Q) / \alpha^{2}\right)$ with the Cochran finite population correction at $5 \%$ level of significance to determine the appropriate sample as 279 respondents. This was proportionately distributed as 257 headteachers and 22 DEOs. Multistage sampling was used to draw the sample. At the first stage, purposive sampling was used to sample 7 administrative regions from 13 regions, resulting in a sample of 735 headteachers and 56 DEOs. At the second stage, proportionate stratified random 
sampling with replacement was used to draw a sample of 257 headteachers from the 735 headteachers and, from the 56 DEOs, 20 DEOs were randomly selected.

The questionnaire had 11 items for each variable, 10 of which were 5-point Likert scale items and 1 open-ended item. School infrastructure policy implementation was operationalized as policy interpretation and policy governance. Each was measure separately. Questionnaire piloting was done on 28 headteachers. The Cronbach alpha coefficient of internal consistency was $\alpha=0.923$ for $X^{1}$, $\alpha=0.866$ for $X^{2}$ and $\alpha=0.826$ for $Y$; signifying the research tool was reliable. Peer review and piloting were used to ensure the validity of the questionnaire. Quantitative data collection was by the drop-and-pick later method.

Data analysis was by path analysis technique using the Andrew Hayes Process tool model 1 to compute the path coefficients, moderation effect and the bootstrap confidence intervals.

\section{Results and Discussions}

\subsection{Response Rate and Parametric Suitability Tests}

The researchers received back 247 (96.1\%) completed head teachers' questionnaires while 20 (90.9\%) DEOs were interviewed. Two DEOs could not be reached for the interview. Before applying parametric methods of analysis and testing, the data was tested to determine whether it fulfilled the assumptions of parametric tests. The Kolmogorov-Smirnov test for normality returned D (247) $=0.053, P=0.095$ for policy interpretation; $\mathrm{D}(247)=0.057, P=0.052$ for policy governance; D (247) $=0.052, P=0.099$ for community participation and D (247) $=0.046, P=0.2$ for performance of construction projects indicating the data was from a normally distributed population. To test for multicollinearity the tolerance value (TV) and its inverse VIF were used. The results were: policy interpretation, $\mathrm{TV}=0.657, \mathrm{VIF}=1.523$; policy governance, $\mathrm{TV}=0.782, \mathrm{VIF}=1.279$; community participation, $\mathrm{TV}=0.987, \mathrm{VIF}=1.013$; which showed absence of multicollinearity. Homogeneity of variance was tested using the Levene statistic. Policy interpretation $\mathrm{F}(29,212)=1.087, P=0.355$; policy governance, $\mathrm{F}(29$, $212)=0.907, P=0.608$; community participation $\mathrm{F}(29,212)=1.546, P=0.051$, showing the variances in $\mathrm{Y}$ were constant at different points of the independent variables.

\subsection{Descriptive Analysis}

The headteachers' responses for the 10, 5-point Likert items per variable were totaled for each variable per school on a scale of 10 - 50 and binned into three groups: disagree, not sure and agree. Descriptive analysis was done on data from questionnaires. The Likert items with a low of 1 and a high of 5 (SD-1, D-2, NS-3, A-4, SA-5). The scale for each variable with 10 Likert items was adopted as: $10<$ Strongly Disagree $<18 ; 18<$ Disagree $<26 ; 26<$ Not Sure $<34 ; 34<$ Agree $<42$; and $42<$ Strongly Agree $<50$ (Carifio \& Perla, 2007). The results are shown in Table 1 below. 
Table 1. Descriptive analysis.

\begin{tabular}{|c|c|c|c|c|c|}
\hline Variable & Response category & Frequency & Per cent & Mean & $\begin{array}{c}\text { Standard } \\
\text { Deviation }\end{array}$ \\
\hline \multirow{4}{*}{$\begin{array}{c}\text { Performance of } \\
\text { construction projects }\end{array}$} & Disagree/low $(10<26)$ & 68 & 27.5 & \multirow{4}{*}{29.60} & \multirow{4}{*}{7.12} \\
\hline & Not sure $(26<34)$ & 109 & 44.2 & & \\
\hline & Agree/high $(34 \leq 50)$ & 70 & 28.3 & & \\
\hline & Total & 247 & 100.0 & & \\
\hline \multirow{4}{*}{$\begin{array}{l}\text { School infrastructure } \\
\text { policy interpretation }\end{array}$} & Disagree/low $(10<26)$ & 64 & 25.9 & \multirow{4}{*}{30.64} & \multirow{4}{*}{8.67} \\
\hline & Not sure $(26<34)$ & 91 & 36.9 & & \\
\hline & Agree/high $(34 \leq 50)$ & 92 & 37.2 & & \\
\hline & Total & 247 & 100.0 & & \\
\hline \multirow{4}{*}{$\begin{array}{l}\text { School infrastructure } \\
\text { policy governance }\end{array}$} & Disagree/low $(10<26)$ & 54 & 21.9 & \multirow{4}{*}{32.41} & \multirow{4}{*}{8.85} \\
\hline & Not sure $(26<34)$ & 85 & 34.4 & & \\
\hline & Agree/high $(34 \leq 50)$ & 108 & 43.7 & & \\
\hline & Total & 247 & 100.0 & & \\
\hline \multirow{4}{*}{$\begin{array}{l}\text { Community } \\
\text { participation }\end{array}$} & Disagree/low $(10<26)$ & 0 & 0 & \multirow{4}{*}{36.74} & \multirow{4}{*}{4.00} \\
\hline & Not sure $(26<34)$ & 53 & 21.5 & & \\
\hline & Agree/high $(34 \leq 50)$ & 194 & 78.5 & & \\
\hline & Total & 247 & 100.0 & & \\
\hline
\end{tabular}

On the performance of construction projects in their schools, 68 (27.5\%) headteachers indicated that it was low, $70(28.3 \%)$ indicating that it was high and 109 (44.2\%) took a lukewarm position. The mean score was 29.60 indicating the headteachers were indifferent as to whether the performance of construction projects in the schools was low or high. Some schools had had a good performance of the construction projects they had undertaken, other schools had poor performance while others had some projects performing well but others realize dismal results. On policy interpretation, 64 (25.9\%) headteachers reported having experienced policy interpretation issues on school infrastructure policy, 92 (37.2\%) headteachers indicated having not experienced such issues while 91 (36.9\%) headteachers were not sure. A further examination of the responses revealed that most of the headteachers who had experienced policy interpretation issues were in rural schools. The mean was 30.64 and the standard deviation 8.67 indicating the average response was in the "not sure" category and data had significant variability.

On policy governance, the headteachers expressed a slightly favourable position with a mean of 32.41 and a standard deviation of 8.85 . Of the headteachers surveyed, 108 (43.7\%) had a favourable opinion on how school infrastructure policy was being administered by the Ministry of Education and Higher Studies [MoEHS\}, 54 (21.9\%) indicated the policy governance practice was wanting while $85(34.4 \%)$ headteachers were indifferent over the issue. This shows that 
more schools believed that school infrastructure policy governance influenced the performance of their school's construction projects. On community participation, 194 (78.5\%) headteachers reported high community participation in school construction projects. No headteacher reported low community participation while $53(21.7 \%)$ headteachers were not sure whether their community participation engagements could be categorized as low or high. With a mean of 36.74, the headteachers were, overall, persuaded that community participation was high in school construction projects. The standard deviation (4.00) show that the responses were narrowly spread around the mean and there were no outliers in the data indicating the respondents agreed that community participation in public primary schools was high. This shows that schools highly depended on the community when undertaking school construction projects. Headteachers sought community involvement and support in school projects since MoEHS was largely unable to support development in schools. Community participation in primary schools was, therefore, a fill-gap measure rather than an enhancement measure.

\subsection{Inferential Analysis}

The first stage of the analysis examined the total effect of school infrastructure policy implementation on the performance of construction projects. Multiple regression analysis was done with policy interpretation and policy governance as the predictors and, the performance of construction projects as the outcome variable. The results are shown in Table 2.

For policy interpretation, the $b$ value was 0.069 indicating a low positive influence that was statistically insignificant $(P=0.210)$. For policy governance, the b value was -0.053 indicating a small negative insignificant influence $(P=0326)$. The constant value $(29.201)$ was statistically significant $(P<0.001)$. Since the independent variables in the model have no significant influence on the performance of construction projects, the model confirms the obvious that when no school construction projects are being undertaken, implementing the school infrastructure policy yields no change in project performance.

\section{Testing hypothesis “a”}

$\mathrm{H}_{\mathrm{O}}$ : School infrastructure policy implementation $\left(X_{1}\right)$ has no total effect on the performance of construction projects $(Y)$.

Table 2. Regression coefficients for total effect of school infrastructure policy implementation on performance of construction projects.

\begin{tabular}{|c|c|c|c|c|c|c|c|c|c|c|}
\hline \multirow[b]{2}{*}{ Model } & \multicolumn{2}{|c|}{$\begin{array}{l}\text { Unstandardized } \\
\text { Coefficients }\end{array}$} & \multirow{2}{*}{$\begin{array}{c}\begin{array}{c}\text { Standardized } \\
\text { Coefficients }\end{array} \\
\text { Beta }\end{array}$} & \multirow[t]{2}{*}{$t$} & \multirow{2}{*}{ Sig. } & \multicolumn{2}{|c|}{$\begin{array}{l}95.0 \% \text { Confidence } \\
\text { Interval for } b\end{array}$} & \multicolumn{3}{|c|}{ Correlations } \\
\hline & $b$ & Std. Error & & & & Lower Bound & Upper Bound & Zero-order & Partial & Part \\
\hline Constant & 29.201 & 2.068 & & 14.123 & 0.000 & 25.128 & 33.274 & & & \\
\hline PI & 0.069 & 0.055 & 0.084 & 1.257 & 0.210 & -0.039 & 0.178 & 0.064 & 0.080 & 0.080 \\
\hline PG & -0.053 & 0.054 & -0.066 & -0.984 & 0.326 & -0.160 & 0.053 & -0.040 & -0.063 & -0.063 \\
\hline
\end{tabular}

Note: Dependent Variable: Performance of Construction Projects, PI: policy interpretation. PG: policy governance. $n=247, \alpha=0.05, \mathrm{R}^{2}=0.008$. 
$\mathrm{H}_{\mathrm{A}}$ : School infrastructure policy implementation $\left(X_{1}\right)$ has a significant total effect on the performance of construction projects $(Y)$.

Since the $b$ values in the total effect model are both insignificant for policy governance and policy interpretation operationalization of school infrastructure policy implementation, the null hypothesis is accepted. School infrastructure policy implementation alone has no total effect on the performance of construction projects when there are no other variables in the model.

The next stage of analysis focused on examining whether community participation moderated the relationship between school infrastructure policy implementation and the performance of construction projects. Path analysis was used with the aid of Hayes Process tool model 1. The results are shown in Table 3.

Table 3 presents the coefficients for the moderation model. The constant was -0.669 and was not significant $(P=0.9713)$. Controlling for community participation $\left(X_{1} \mid X_{2} \rightarrow Y\right)$, school infrastructure policy implementation exerted a significant positive influence on the performance of construction projects $(b=$ $1.1558, P=0.0414)$. This shows that school infrastructure policy predicts the performance of construction projects when the community participate in the construction projects. Controlling for school infrastructure policy implementation $\left(X_{2} \mid X_{1} \rightarrow Y\right)$, community participation exerted a direct positive effect ( $b=$ 0.8070 ) on the performance of construction projects, but this effect was not statistically significant ( $t=1.6001, P=0.1109$ ). This shows that community participation does not exert a significant direct effect on the performance of construction projects when school infrastructure policy is being implemented. This is confirmed by the value of $\mathrm{R}^{2}$ of 0.0279 , indicating that only an insignificant $2.8 \%$ of variations in the performance of construction projects are explained by the combination of community participation and school infrastructure policy implementation

The coefficient for the interaction term $\left(X_{1}{ }^{*} X_{2}\right)$ was -0.0309 and was significant $(P=0.0438)$. This indicates that community participation moderates the relationship between school infrastructure policy implementation and the performance of construction projects. The interaction term exerted a negative direct influence on the performance of construction implying that performance of

Table 3. Regression coefficients for community participation moderation model.

\begin{tabular}{ccccccc}
\hline & \multicolumn{1}{c}{} & & \multicolumn{2}{c}{ Confidence Interval } \\
\hline Model & Coefficient. & Se & $t$ value & $P($ sig $)$ & LLCI & ULCI \\
\hline Constant & -0.6690 & 18.6017 & -0.0360 & 0.9713 & -37.3102 & 35.9722 \\
$\begin{array}{c}\text { School infrastructure } \\
\text { policy implementation }\end{array}$ & 1.1558 & 0.5638 & 2.0502 & 0.0414 & 0.0453 & 2.2663 \\
$\begin{array}{c}\text { Community participation } \\
\text { Interaction Term }\end{array}$ & 0.8070 & 0.5043 & 1.6001 & 0.1109 & -0.1864 & 1.8004 \\
\hline
\end{tabular}

Note: Independent variable: School infrastructure policy implementation, $n=247, \alpha=0.05, \mathrm{R}^{2}=0.279(p=$ 0.0757). 
construction projects reduces when the community participate in construction projects in schools that implement the school infrastructure policy.

The model shows that a linear relationship exists among the variables. School infrastructure policy implementation and community participation are positively related to the performance of construction projects while the interaction term is negatively related to the performance of construction projects.

The path coefficients are shown in Figure 2.

Figure 2 shows the path coefficients for the paths in the model used to test hypotheses.

\section{Testing hypothesis " $b$ "}

$\mathrm{H}_{\mathrm{O}}$ : Community participation $\left(X_{2}\right)$ does not moderate the relationship between school infrastructure policy implementation $\left(X_{1}\right)$ and the performance of construction projects $(Y)$.

$$
\mathrm{H}_{\mathrm{O}}: p_{23}=0 ; p_{22} \neq 0
$$

$\mathrm{H}_{\mathrm{A}}$ : Community participation $\left(X_{2}\right)$ significantly moderates the relationship between school infrastructure policy implementation $\left(X_{1}\right)$ and the performance of construction projects $(Y)$.

$$
\mathrm{H}_{\mathrm{A}}: p_{23} \neq 0 ; p_{22}=0
$$

Moderation occurs when $X_{1}{ }^{\star} X_{2} \rightarrow Y$ effect is significant but the $X_{2} \mid X_{1} \rightarrow Y$ effect is not (Awang, 2012). The path coefficient $p_{23}=-0.0309$ was significant $(P=$ $0.0438)$, but the path coefficient $p_{22}=0.8070$ was not significant $(P=0.1109)$. The null hypothesis is rejected and the alternative hypothesis accepted. This shows that a low negative moderation is exerted by community participation in the relationship between school infrastructure policy implementation and performance of construction projects.

The study further investigated the extent of the moderation by testing the path coefficient $p_{21}$ on the $X_{1} \mid X_{2} \rightarrow Y$ path. The following hypothesis was tested.

$\mathrm{H}_{\mathrm{O}}: X_{2}$ completely moderates the relationship between $X_{1}$ and $Y$.

$$
\mathrm{H}_{\mathrm{O}}: p_{21}=0
$$

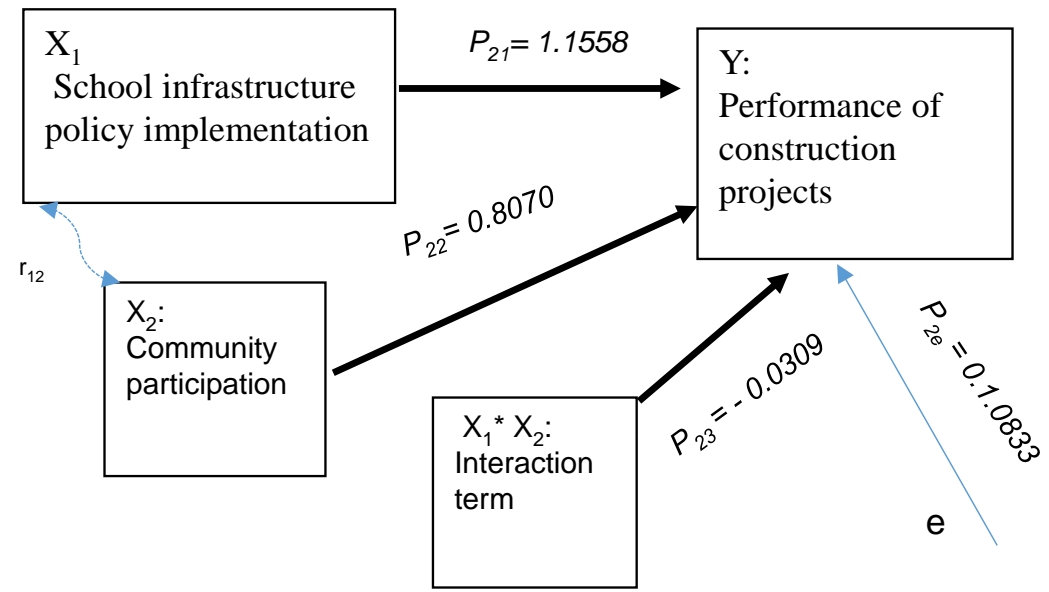

Figure 2. Path analysis model for community participation. 
$\mathrm{H}_{\mathrm{A}}: X_{2}$ partially moderates the relationship between $X_{1}$ and $Y$ :

$$
\mathrm{H}_{\mathrm{A}}: p_{21} \neq 0
$$

with $p_{21}=1.1558(t=2.0502, P=0.0414)$ the null hypothesis is rejected and the alternative hypothesis accepted. The moderation exerted by community participation in the relationship between school infrastructure policy implementation and performance of construction projects was determined to be partial.

The partial moderation was significantly low and negative $\left(p_{23}=-0.0309\right)$ showing that the influence of school infrastructure policy implementation on the performance of construction projects reduces slightly when the community participate in construction projects. This can be attributed to some elements of the context. Community participation in Somaliland's public primary schools is a national policy initiative. Schools participate the community to comply with the policy as much as to tap into the communities' social capital. Community participation processes require time investment and as a result, increase the overall project duration by slowing down project processes and decision making due to the time required for consultations. The result may be: fewer projects mounted, delayed completion of projects, diverse interests leading to dissatisfactions in the projects among others; hence the slight negative moderation effect.

To understand the low negative partial moderation exerted by community participation on the relationship between school infrastructure policy implementation and performance of construction projects, further analysis of the moderation was done using the Johnson-Neyman technique. Twenty-two regressions of $X_{1}$ on $Y$ were done at 22 different values of the moderator from the minimum value (27) to the maximum value (48). Part of the output is shown in Table 4 with the complete results in Appendix 1.

The results of the Johnson-Neyman analysis show the relationship that exists between school infrastructure policy implementation $\left(X_{1}\right)$ and the performance

Table 4. Conditional effect of focal predictor at moderator values-Johnson-Neyman Method.

\begin{tabular}{ccccccc}
\hline & & & & & Confidence Interval \\
\hline $\begin{array}{c}\text { Values of community } \\
\text { participation }\end{array}$ & Effect & se & $t$ & $p$ & LLCI & ULCI \\
\hline 27.0000 & 0.3221 & 0.1607 & 2.0050 & 0.0461 & 0.0057 & 0.6386 \\
28.0500 & 0.2897 & 0.1459 & 1.9855 & 0.0482 & 0.0023 & 0.5771 \\
28.6848 & 0.2701 & 0.1371 & 1.9698 & 0.0500 & 0.0000 & 0.5402 \\
29.1000 & 0.2573 & 0.1314 & 1.9573 & 0.0515 & -0.0016 & 0.5162 \\
30.1500 & 0.2249 & 0.1174 & 1.9156 & 0.0566 & -0.0064 & 0.4561 \\
31.2000 & 0.1924 & 0.1039 & 1.8524 & 0.0652 & -0.0122 & 0.3971 \\
32.2500 & 0.1600 & 0.0912 & 1.7547 & 0.0806 & -0.0196 & 0.3396 \\
\hline
\end{tabular}

Note: The table shows the conditional effect of $X_{1}$ on $Y$ for 7 lowest values of the moderator. Results for 15 other values of the moderator higher than 32.2500 were all insignificant (Appendix 1). Focal Predictor School Infrastructure Policy Implementation. Moderator - Community Participation. $n=247, \alpha=0.05$. 
of construction projects $(Y)$ for different values of the moderator $\left(X_{1} \mid X_{2} \rightarrow Y\right)$. The minimum value for community participation in the Likert scale data was 27 and the maximum value was 48 on a scale of $10 \rightarrow 50$. For values of community participation $\geq 29.1000$ and running up to 48.000 , the relationship between $X_{1}$ and $Y$ was not significant. However, for low values of community participation $(27.000 \rightarrow 28.6848)$, the relationship between $X_{1}$ and $Y$ was significant. This shows that, in this moderation model, the relationship between school infrastructure policy implementation and performance of construction projects controlling for community participation $\left(X_{1} \mid X_{2} \rightarrow Y\right)$ is significant at low levels of community participation and insignificant at moderate and high levels of community participation. The partial moderation effect of community participation on the $X_{1} \rightarrow Y$ relationship therefore only exists at lower values of the moderator. At moderate and higher values of the moderator, the $X_{1} \rightarrow Y$ relationship disappears resulting in complete moderation.

This shows that schools that reported low levels of community participation also realized a positive influence of school infrastructure policy implementation on the performance of construction projects, while schools that reported moderate and high levels of community participation did not. Community participation doesn't only bring positive influences to projects but negative influences as well. The more the participants brought onboard a project process, and the more their participation, the more diverse the interests represented, the more the disagreements, conflicts and time taken to complete the project. Higher levels of community participation can be counterproductive to the goals of the participation process, the goals of the policy and the goals of the school.

\section{Conclusion}

Community participation has a significant low and negative partial moderation effect on the relationship between school infrastructure policy implementation and performance of construction projects. A linear model exists among the three variables. The negative moderation was due to the downsides of community participation in school projects. The partial moderation effect of community participation on the relationship between school infrastructure policy implementation and performance of construction projects only exists at lower values of the moderator. At higher values of the moderator, the relationship wanes resulting in complete moderation. Schools that reported low levels of community participation also realized a positive influence of school infrastructure policy implementation on the performance of construction projects, while schools that reported moderate and high levels of community participation did not. High levels of community participation can be counterproductive to the goals of the participation process, the goals of the policy and the goals of the school.

Overall, the performance of construction projects in public primary schools was satisfactory. Completed construction projects significantly realized their set standards, attained functionality and the project outcomes were accepted by 
teachers and schools' administration. Since high levels of community participation can be counterproductive to the goals of the participation process, the goals of the policy and the goals of the school; headteachers need to be sensitized on the importance of low to moderate meaningful community participation so that they don't go overboard in community participation activities and eventually reduce project performance in their schools.

Community participation in school infrastructure projects is therefore a beneficial method of establishing infrastructure in public schools especially in cases where the government is short of capitation to consistently finance school development.

Further research is needed to elaborate the finding that low levels of community participation attain partial moderation of the relationship between school infrastructure policy implementation and performance of construction projects, while high levels of community participation attain full moderation. It would be meaningful to find out whether this finding replicates in other sectors, with other policies and with other communities.

\section{Acknowledgements}

The authors acknowledge and thank all respondents who participated in this study and all the research assistants who facilitated data collection.

\section{Authors Contributions}

SJK formulated and undertook the study, while CMR and JMM provided guidance and supervised the work.

\section{Conflicts of Interest}

The authors declare that there are no competing interests.

\section{References}

Awang, Z. (2012). A Handbook on SEM Structural Equation Modelling: SEM Using AMOS Graphic (5th ed.). Kota Baru: Universiti Teknologi Mara Kelantan.

Bengle, T., \& Sorensen, J. (2016). Integrating Popular Education into a Model of Empowerment Planning. Community Development, 1-19.

Brown, A. C., Stern, J., Tenenbaum, B., \& Gencer, D. (2006). Handbook for Evaluating Infrastructure Regulatory Systems. Washington DC: The World Bank. https://doi.org/10.1596/978-0-8213-6579-3

Burki, S. J., Perry, G. E., \& Dillinger, W. R. (2009). Beyond the Center: Decentralizing the State. Washington DC: The World Bank.

Burns, D., \& Taylor, M. (2000). Auditing Community Participation-An Assessment Handbook. Bristol: Policy Press.

Carifio, J., \& Perla, R. J. (2007). Ten Common Misunderstandings, Misconceptions, Persistent Myths and Urban Legends about Likert Scales and Likert Response Formats and their Antidotes. Journal of Social Sciences, 3, 106-116.

https://doi.org/10.3844/jssp.2007.106.116

Chambers, R. (2013). Rural Development: Putting the Last First. London: Longman. 
https://doi.org/10.4324/9781315835815

Chan, A. P. C., \& Chan, A. P. L. (2004). Key Performance Indicators for Measuring Construction Success. Benchmarking: An International Journal, 11, 203-221. https://doi.org/10.1108/14635770410532624

Chan, A. P. C., Scott, D., \& Lam, E. W. M. (2002). Framework of Success Criteria for Design/Build Projects. Journal of Management in Engineering, 18, 120-128. https://doi.org/10.1061/(ASCE)0742-597X(2002)18:3(120)

Coglianese, C. (2012). Measuring Regulatory Performance: Evaluating the Impact of Regulation and Regulatory Policy. Expert Paper No. 1, Paris: OECD.

Cooke, B., \& Kothari, U. (2010). Participation: The New Tyranny. London: New York Publishing.

Damon, A., Glewwe, P., Wisniewski, S., \& Sun, B. (2016). Education in Developing Countries: What Policies and Programmes Affect Learning and Time in School? Stockholm: Expertgruppen för biståndsanalys (EBA).

De Wit, J. (2010). Decentralized Management of Solid Waste in Mumbai Slums: Informal Privatization through Patronage. International Journal of Public Administration, 33, 767-777. https://doi.org/10.1080/01900692.2010.514450

Gertler, P., Patrinos, H., \& Rubio-Codina, M. (2008). Empowering Parents to Improve Education: Evidence from Rural Mexico. The World Bank, Policy Research Working Paper Series: 3935.

Hall, J. (2013). Pragmatism, Evidence, and Mixed Methods Evaluation (Special Issue: Mixed Methods and Credibility of Evidence in Evaluation). New Directions for Evaluation, 2013, 15-26. https://doi.org/10.1002/ev.20054

Jiang, H., \& Carroll, J. M. (2009). Social Capital, Social Network and Identity Bonds: A Reconceptualization. Proceedings of the 2009 Community and Technology Conference. https://dl.acm.org/doi/abs/10.1145/1556460.1556469

Kaushik, V., \& Walsh, C. A. (2019). Pragmatism as a Research Paradigm and Its Implications for Social Work Research. Social Sciences, 8, 1-17. https://doi.org/10.3390/socsci8090255

Lai, B., \& Thyne, C. (2007). The Effect of Civil War on Education, 1980-97. Journal of Peace Research, 44, 277-292. https://doi.org/10.1177/0022343307076631

Sifuna, D. N., \& Sawamura, N. (2009). Challenges of Quality Education in Sub-Saharan African Countries. New York: Nova Science Publishers.

UNESCO United Nations Educational, Scientific and Cultural Organization (2014). The Right to Education: Law and Policy Review Guidelines. Paris: Author.

Vandevelde, A., Dierdonck, R. V., \& Debackere, K. (2002). Practitioners View on Project Performance: A Three-Polar Construct. Vlerick Working Papers 2002/06, Vlerick Leuven: Gent Management School. 
Appendix 1: Conditional Effect of Focal Predictor at Moderator Values-Johnson-Neyman Technique

\begin{tabular}{|c|c|c|c|c|c|c|}
\hline \multirow[b]{2}{*}{$\begin{array}{c}\text { Values of community } \\
\text { participation }\end{array}$} & \multirow[b]{2}{*}{ Effect } & \multirow[b]{2}{*}{ se } & \multirow[b]{2}{*}{$t$} & \multirow[b]{2}{*}{$p$} & \multicolumn{2}{|c|}{ Confidence Interval } \\
\hline & & & & & LLCI & ULCI \\
\hline 27.0000 & 0.3221 & 0.1607 & 2.0050 & 0.0461 & 0.0057 & 0.6386 \\
\hline 28.0500 & 0.2897 & 0.1459 & 1.9855 & 0.0482 & 0.0023 & 0.5771 \\
\hline 28.6848 & 0.2701 & 0.1371 & 1.9698 & 0.0500 & 0.0000 & 0.5402 \\
\hline 29.1000 & 0.2573 & 0.1314 & 1.9573 & 0.0515 & -0.0016 & 0.5162 \\
\hline 30.1500 & 0.2249 & 0.1174 & 1.9156 & 0.0566 & -0.0064 & 0.4561 \\
\hline 31.2000 & 0.1924 & 0.1039 & 1.8524 & 0.0652 & -0.0122 & 0.3971 \\
\hline 32.2500 & 0.1600 & 0.0912 & 1.7547 & 0.0806 & -0.0196 & 0.3396 \\
\hline 33.3000 & 0.1276 & 0.0797 & 1.6009 & 0.1107 & -0.0294 & 0.2846 \\
\hline 34.3500 & 0.0952 & 0.0700 & 1.3595 & 0.1752 & -0.0427 & 0.2331 \\
\hline 35.4000 & 0.0627 & 0.0629 & 0.9972 & 0.3197 & -0.0612 & 0.1867 \\
\hline 36.4500 & 0.0303 & 0.0594 & 0.5104 & 0.6103 & -0.0867 & 0.1474 \\
\hline 37.5000 & -0.0021 & 0.0601 & -0.0348 & 0.9723 & -0.1205 & 0.1163 \\
\hline 38.5500 & -0.0345 & 0.0649 & -0.5320 & 0.5952 & -0.1623 & 0.0933 \\
\hline 39.6000 & -0.0669 & 0.0729 & -0.9181 & 0.3595 & -0.2105 & 0.0767 \\
\hline 40.6500 & -0.0994 & 0.0833 & -1.1933 & 0.2339 & -0.2634 & 0.0647 \\
\hline 41.7000 & -0.1318 & 0.0952 & -1.3843 & 0.1675 & -0.3193 & 0.0557 \\
\hline 42.7500 & -0.1642 & 0.1082 & -1.5178 & 0.1304 & -0.3773 & 0.0489 \\
\hline 43.8000 & -0.1966 & 0.1219 & -1.6131 & 0.1080 & -0.4367 & 0.0435 \\
\hline 44.8500 & -0.2290 & 0.1361 & -1.6830 & 0.0937 & -0.4971 & 0.0390 \\
\hline 45.9000 & -0.2615 & 0.1507 & -1.7355 & 0.0839 & -0.5582 & 0.0353 \\
\hline 46.9500 & -0.2939 & 0.1655 & -1.7759 & 0.0770 & -0.6198 & 0.0321 \\
\hline 48.0000 & -0.3263 & 0.1805 & -1.8077 & 0.0719 & -0.6819 & 0.0293 \\
\hline
\end{tabular}

Note: $n=247, \alpha=0.05$. The table shows the conditional effect of $X^{1}$ on $Y$. 